\title{
Testing pollution haven hypothesis in five Southeast Asian countries
}

\author{
Thi Kim Nhung NGUYEN ${ }^{1}$ and Lan Ngoc $\mathrm{HO}^{2}$ \\ ${ }^{1}$ Faculty of Economics and Business Administration, Ha Tinh Univeristy, Vietnam \\ ${ }^{2}$ Faculty of Economics, Law and Logistics, Ba ria - Vung Tau University, Vietnam
}

\begin{abstract}
This paper aims to test the validity of pollution haven hypothesis in a group of five Southeast Asian countries by examining the effect of foreign direct investment and other factors on $\mathrm{CO} 2$ emission. Fixed effect model with instrumental variables are used in a data set for 1996-2013 period, which then points out that foreign direct investment and energy consumption contributes to pollution in Southeast Asian countries: Cambodia, Vietnam, Thailand, Philippines and Malaysia. Trade and urbanization are found to be insignificant in explaining $\mathrm{CO} 2$ emission.

Keywords:foreign direct investment, pollution haven hypothesis, carbon dioxide emission, environmental stringency
\end{abstract}

\section{Introduction}

Southeast Asian is considered a dynamic economic zone in the world, which has attracted a large amount of foreign direct investment (FDI). In 2018, FDI inflows into ASEAN countries reached 155 billion US dollars, accounting for $15.5 \%$ of global FDI (UNCTAD, 2019), increasing 5\% in 2019 with a record level of 156 billion US dollars (UNCTAD, 2020). FDI is one of the main growth engines in the region. However, the rising level of FDI flows from developed countries to developing ones poses a concern about the environmental impacts (Zeng \& Eastin, 2012).

Due to the importance of FDI-environment nexus, many economists have extensively examined the link between FDI and environmental stringency. One of noticeable theory is the Pollution Haven Hypothesis (PHH), which posits that the environmental stringency between countries influences the industrial location. Companies always minimize their operation cost by investing in countries with cheap labor, abundant natural resources and low operation cost. Meanwhile, in order to attract FDI authorities in developing countries where the operation cost is low tend to loosen their environmental regulations. As a result, developing countries become pollution havens for polluting firms and industries (M. A. Cole, 2004; G. Grossman \& Krueger, 1991). PHH has been a hotly debated issue for many researchers. While some validate the hypothesis, others disapprove it. Because of contrasting results, further research is needed. In testing $\mathrm{PHH}$, studies have linked environmental stringency to FDI (Dean, Lovely, \& Wang, 2009; Demena \& Afesorgbor, 2020; Fredriksson, List, \& Millimet, 2003; Guzel \& Okumus, 2020; Hanif, Faraz Raza, Gago-de-Santos, \& Abbas, 2019; M. Khan, 2018; Matthew, Robert, \& Per, 2006; Tang, 2015) or trade (M. A. Cole, 2004; G. Grossman \& Krueger, 1991). This study aims to study the impact of FDI on pollution in a set of five ASEAN countries, including Cambodia, Malaysia, The Philippines, Thailand and Vietnam.

Originally, PHH was utilized to study the impact of trade on environment. This theory was first mentioned by Pethig (1976) and McGuire (1982) when they studied the effect of environmental regulations on firm locations, then developed by G. M. Grossman and Krueger (1992) and Copeland and Taylor (2004). G. M. Grossman and Krueger (1992) divided the environmental impact of trade into: the scale effect, the composition effect and the technique effect. The scale effect states that trade has a positive impact on the environment because trade is associated with increasing energy consumption at low income. When income reaches a certain level, pollution will be mitigated (EKC relationship). The composition effect reflects the change in structure of the economy as trade changes production pattern. The composition effect depends on countries' comparative advantage in producing pollution intensive goods and the stringency of environmental regulation.Meanwhile, the technique effect refers to the impact of the change in the technology brought about by trade. If foreign companies brings with them clean technology, they will reduce pollution in the host country. However, international trade with obsolete technology is harmful to the environment. The environmental regulation imposed by countries 
will have an impact on plant location and then trade inflows. Trade openness is used in the equation examining the effect of FDI on the environment by some studies such as Ren, Yuan, Ma, and Chen (2014); Omri, Nguyen, and Rault (2014)Ansari, Khan, and Ganaie (2019), Kahouli and Omri (2017); Solarin, Al-Mulali, Musah, and Ozturk (2017)Salehnia, Karimi Alavijeh, and Salehnia (2020); Shao, Wang, Zhou, and Balogh (2019). Following literature, trade is also included in this study.

One of the fundamental challenges facing pollution haven hypothesis studies is how to measure environmental stringency. There are three commonly used measures of environmental stringency: measure of environmental regulation, extent of environmental registration and the amount of pollution emission (M. Cole, Elliott, \& Zhang, 2017). Some measures of pollution emissions are pollutants such as $\mathrm{CO} 2, \mathrm{SO} 2$, and PM 2.5. Among these, $\mathrm{CO} 2$ emission, which is the main cause of global warming, is the most commonly used measure. A large number of studies use $\mathrm{CO} 2$ as proxy for environmental stringency such as Hoffmann, Lee, Ramasamy, and Yeung (2005); Liu, Qu, and Zhao (2019); Sapkota and Bastola (2017); Shao et al. (2019); Solarin et al. (2017); Ansari et al. (2019); Sarkodie and Strezov (2019). Following literature, this study uses $\mathrm{CO} 2$ as a proxy for environmental stringency.

How energy use affects environment is also a controversial issue. Energy consumption plays a vital role in economic activities and human life but energy consumption leads to $\mathrm{CO} 2$ emission. Particularly, fossil fuel consumption is the most serious cause of $\mathrm{CO} 2$ emission. Power plants, manufacturing factories, the transport sector are responsible for increasing amount of carbon dioxide in the air. Some studies use energy consumption as a control variable in studying the impact of foreign direct investment in $\mathrm{CO} 2$ emission such as Solarin et al. (2017); Sun, Zhang, and Xu (2017); Liu et al. (2019); Sabir, Qayyum, and Majeed (2020).

Estimating a model of $\mathrm{CO} 2$ emission without taking urbanization into consideration will underestimate carbon dioxide emission (Sadorsky, 2014). According to ecological modernization and urban environmental transition theories, urbanization can affect $\mathrm{CO} 2$ emissions positively or negatively. The theory of ecological modernization states that in early stage of development, countries consider economic growth as priority. Therefore, urbanization or income increases rapidly at the expense of environmental quality. However, as the economy growth reaches a certain level and environment becomes highly polluted, the need for cleaner environment arises. At this stage, pollution level is reduced thanks to better technology and urbanization (Crenshaw \& Jenkins, 1996; Mol \& Spaargaren, 2000). Similarly, the theory of urban environmental

\section{ISSN 2455-6378}

transition postulates that the development of cities is associated with manufacturing factories that impede the environment. Nevertheless, as cities become wealthier, environmental degradation is decreased as cleaner technology and strict environmental regulations are applied. Simultaneously, the demand for more pollution intensive products increases as cities becomes more prosperous. Taking the two effects into consideration, the net effect of urbanization on pollution is still ambiguous (McGranahan, 2001). When examining foreign direct investment and $\mathrm{cO} 2$ emission nexus, several studies such as M. A. Cole and Elliott (2005), M. A. Cole and Fredriksson (2009), Omri et al. (2014), Azam, Khan, Zaman, and Ahmad (2015), Solarin et al. (2017) included urbanization in the model.

\section{Review of Literature}

According to pollution haven hypothesis, multinational companies are tempted to produce their pollution intensive goods in developing countries where the environmental regulations and enforcement are weaker. While some researchers validated pollution haven hypothesis regarding FDI and environmental stringency (Cai, $\mathrm{Lu}, \mathrm{Wu}, \& \mathrm{Yu}$, 2016; M. A. Cole \& Elliott, 2005; Hoffmann et al., 2005; Millimet \& Roy, 2016; Pao \& Tsai, 2011; Sarkodie \& Strezov, 2019; Tang, 2015; Xing \& Kolstad, 2002), other disapproved this hypothesis (Atici, 2012; Kahouli \& Omri, 2017; Kearsley \& Riddel, 2010; List, McHone, \& Millimet, 2004). Some other studied found mixed results of pollution haven hypothesis (Fredriksson et al., 2003; Naughton, 2014; Rezza, 2013). The validation of pollution haven hypothesis also depends on the type of FDI (Rezza, 2013; Tang, 2015). Tang (2015) found that inward FDI is sensitive to environmental stringency but export-oriented FDI is more sensitive to local market-oriented FDI. Some research analyze pollution haven hypothesis at country or regional level (Cai et al., 2016; Dean et al., 2009; Guzel \& Okumus, 2020; List \& Co, 2000; Sarkodie \& Strezov, 2019; Wolfgang \& Arik, 2002; Xing \& Kolstad, 2002). Other studies are conducted at firm or industry level (Chung, 2014; Hanna, 2010; Javorcik \& Wei, 2003; Kahouli \& Omri, 2017). The various results are due to different methodologies, variables, countries and time periods. 
Table 2.1 Summary of literature review on pollution haven hypothesis

\begin{tabular}{|c|c|c|c|c|}
\hline Author & Countries & Period & Methods & Pollution haven hypothesis \\
\hline $\begin{array}{l}\text { Xing and } \\
\text { Kolstad (2002) }\end{array}$ & US & $1985-1990$ & $\begin{array}{l}\text { Ordinary Least } \\
\text { Squares, Instrumental } \\
\text { Variable }\end{array}$ & $\begin{array}{l}\text { Yes for heavily polluting } \\
\text { industries and not for less } \\
\text { polluting industries }\end{array}$ \\
\hline $\begin{array}{l}\text { Dean et al. } \\
(2009)\end{array}$ & China & 1993-1996 & $\begin{array}{l}\text { Nested and } \\
\text { Conditional logit }\end{array}$ & $\begin{array}{l}\text { Yes for polluting industries } \\
\text { from Macao, Taiwan and } \\
\text { Hong Kong; No for Chinese } \\
\text { non ethically }\end{array}$ \\
\hline $\begin{array}{l}\text { M. A. Cole and } \\
\text { Elliott }(2005)\end{array}$ & $\begin{array}{l}\text { US outward to } \\
\text { Mexico, Brazil }\end{array}$ & 1984-1994 & $\begin{array}{l}\text { Fixed effect, random } \\
\text { effect }\end{array}$ & Yes \\
\hline $\begin{array}{l}\text { Pao and Tsai } \\
(2011)\end{array}$ & $\begin{array}{l}\text { Brazil, Russian } \\
\text { Federation, India, } \\
\text { and China(BRIC } \\
\text { countries) }\end{array}$ & $1980-2007$ & $\begin{array}{l}\text { Vector Error } \\
\text { Correction Model }\end{array}$ & Yes \\
\hline Rezza (2013) & Norwegian & $1996-2005$ & Fixed effect & $\begin{array}{l}\text { No for average FDI but Yes } \\
\text { for vertical FDI }\end{array}$ \\
\hline $\begin{array}{l}\text { Kahia, Ben Jebli, } \\
\text { and Belloumi } \\
(2019)\end{array}$ & $\begin{array}{ll}\text { Six } & \text { African } \\
\text { countries } & \end{array}$ & $1971-2009$ & $\begin{array}{l}\text { Autoregressive } \\
\text { Distributed Lag }\end{array}$ & Yes \\
\hline Naughton (2014) & 28 OECD countries & $1990-2000$ & $\begin{array}{l}\text { Ordinary } \quad \text { Least } \\
\text { Squares }\end{array}$ & 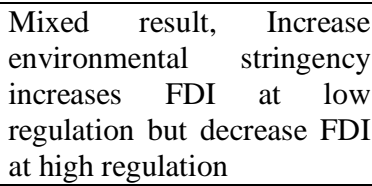 \\
\hline Tang (2015) & United States & $1999-2003$ & 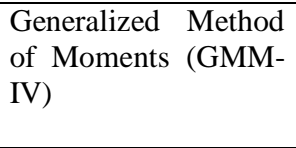 & $\begin{array}{l}\text { Yes, export oriented FDI is } \\
\text { more sensitive to } \\
\text { environmental regulation } \\
\text { than import oriented FDI }\end{array}$ \\
\hline Cai et al. (2016) & China & $1992-2001$ & $\begin{array}{l}\text { Difference- } \\
\text { Difference- in } \\
\text { Differences }\end{array}$ & Yes \\
\hline $\begin{array}{l}\text { Bakirtas and } \\
\text { Cetin (2017) }\end{array}$ & $\begin{array}{l}\text { Indonesia, Mexico, } \\
\text { South Korea, } \\
\text { Turkey, Australia }\end{array}$ & $1982-2011$ & Panel VAR model & Yes \\
\hline $\begin{array}{l}\text { Kahouli and } \\
\text { Omri (2017) }\end{array}$ & $\begin{array}{l}14 \text { home countries } \\
\text { and } 29 \text { host } \\
\text { countries joining } \\
\text { six regional trade } \\
\text { agreements }\end{array}$ & $1990-2011$ & $\begin{array}{l}\text { Fixed effect, random } \\
\text { effect and System } \\
\text { Generalized Method } \\
\text { of Moments }\end{array}$ & No \\
\hline $\begin{array}{l}\text { Koçak and } \\
\text { Şarkgüneşi } \\
(2018)\end{array}$ & Turkey & $1974-2013$ & $\begin{array}{l}\text { Structural break co- } \\
\text { integration, DOLS }\end{array}$ & Yes \\
\hline $\begin{array}{l}\text { Destek and } \\
\text { Okumus (2019) }\end{array}$ & $\begin{array}{l}\text { Ten newly } \\
\text { industrialized } \\
\text { countries }\end{array}$ & $1982-2013$ & $\begin{array}{l}\text { Error correction } \\
\text { based cointegration }\end{array}$ & $\begin{array}{l}\text { No, the U-shaped } \\
\text { relationship between FDI } \\
\text { and ecological footprint }\end{array}$ \\
\hline $\begin{array}{l}\text { Hanif et al. } \\
(2019)\end{array}$ & $\begin{array}{l}\text { Emerging Asian } \\
\text { economies }\end{array}$ & $1990-2013$ & ARDL model & Yes \\
\hline Liu et al. (2019) & $\begin{array}{l}29 \text { provinces in } \\
\text { China }\end{array}$ & $1996-2015$ & $\begin{array}{l}\text { Fixed effects panel } \\
\text { data partially linear } \\
\text { additive model }\end{array}$ & $\begin{array}{l}\text { No, the } \mathrm{N} \text {-shaped } \\
\text { relationship between FDI } \\
\text { and } \mathrm{Co} 2 \text { emission }\end{array}$ \\
\hline $\begin{array}{l}\text { M. A. Khan and } \\
\text { Ozturk }(2020)\end{array}$ & 17 Asian countries & $1980-2014$ & $\begin{array}{l}\text { Modified ordinary } \\
\text { least squares }\end{array}$ & Yes \\
\hline
\end{tabular}


Recently, there have been an increasing number of studies examining pollution haven hypothesis in Southeast Asian countries, a dynamic economic region. When studying pollution haven hypothesis in Southeast Asian countries, most studies used the same of 5 countries sample, including Singapore, Thailand, Philippines, Malaysia, Indonesia (Baek, 2016; Guzel \& Okumus, 2020; Merican, Yusop, Noor, \& Law, 2007; Zhu, Duan, Guo, \& Yu, 2016) to examine the effect of FDI on $\mathrm{CO} 2$ emission. The reason for choosing these countries is their data availability for a long period of time.

Merican et al. (2007) used ARDL technique to test the impact of FDI on $\mathrm{CO} 2$ emission in these countries in the 1970-2001 period. Their results found that FDI contributed to pollution in Thailand, Malaysia and The Philippines while FDI had a negative relation with pollution in Indonesia. The result is insignificant for Singapore. Using panel data approach with pooled mean group estimator, Baek (2016) studied FDI-income-energy-environment nexus and confirmed the existence of pollution haven hypothesis. Similarly, income and energy consumption are found to have a detrimental impact on environment quality. Guzel and Okumus (2020) also examined pollution haven hypothesis in this five sample countries for the 1981-2014 period. Accounting for cross sectional dependence and slope heterogeneity, they found that inward FDI exacerbated CO2 emission. Zhu et al. (2016) utilized panel quantile regression to examine the impact of FDI, economic growth and energy consumption on $\mathrm{CO} 2$ emission. Their results indicate that the effect of independent variables vary across quantiles. There is not enough evidence to validate $\mathrm{PHH}$ in lower income countries where FDI is negatively associated with $\mathrm{CO} 2$ emission. However, in middle and highincome countries, FDI is positively associated with pollution, confirming pollution halo hypothesis. Using co-integration and granger causality approach, Chandran and Tang (2013) also studied the dynamic relationship between $\mathrm{CO} 2$ emission, FDI, energy consumption in road transport and economic growth in the same set of ASEAN 5 countries, but the pollution haven hypothesis is not confirmed in these countries.

Most studies about PHH in Southeast Asian countries often focus on the five countries group Singapore, Thailand, Philippines, Malaysia, and Indonesia because of data availability for a long period. However, recently Vietnam and Cambodia has emerged as a new attractive destination for FDI investors. However, this research examines the pollution haven hypothesis in Southeast Asian region by studying the impact of FDI on $\mathrm{CO} 2$ emission in a different set of countries, namely Cambodia, Thailand, Vietnam, Philippines, and Malaysia.

\section{Materials and Methods}

This research utilizes annual panel data covering the 1996-2013 period for the following developing countries in Southeast Asia: Cambodia, Malaysia, The Philippines, Thailand and Vietnam. The data is taken from the World Bank data source: World Development Indicators. Energy use in Vietnam is not available before 2013 so the time span for the whole countries is limited from 1996 to 2013 in order to have a balanced panel data set. Based on existing literature, the following variables are included in the model to examine the impact of FDI on $\mathrm{CO} 2$ emission in five Southeast Asian countries.

Table 3.1. Description of data source

\begin{tabular}{|l|l|}
\hline Variable & Definition \\
\hline CO2 & Metric tons per capita \\
\hline Energy & Energy use (kg of oil equivalent per capita) \\
\hline Fdi & $\begin{array}{l}\text { Foreign direct investment, net inflows (\% } \\
\text { of GDP) }\end{array}$ \\
\hline Trade & $\begin{array}{l}\text { Sum of exports and imports of goods and } \\
\text { services as percentage of GDP }\end{array}$ \\
\hline Urban & $\begin{array}{l}\text { Urban population as percentage of total } \\
\text { population }\end{array}$ \\
\hline
\end{tabular}

The panel data approach is commonly utilized to capture both time series and cross sectional dimensions (Shen, Wang, Liu, \& Chu, 2019). Following literature, this research uses fixed effect and random effect to examine the effect of FDI on $\mathrm{CO} 2$ emission on ASEAN-5 countries. The model is specified as follows:

$$
\begin{aligned}
\operatorname{lnCO2}_{\text {it }}=\beta_{\mathrm{o}}+ & \beta_{1} \operatorname{lnFDI}_{\mathrm{it}}+\beta_{2} \operatorname{lnUrban}_{\mathrm{it}} \\
& +\beta_{3} \operatorname{lnenergy}_{\mathrm{it}}+\beta_{4} \operatorname{lntrade}_{\mathrm{it}} \\
& +\alpha_{\mathrm{i}}+\gamma_{\mathrm{t}}+\varepsilon_{\mathrm{it}}
\end{aligned}
$$

$\mathrm{CO} 2$ emission is used as a proxy for environmental stringency. Variables are transformed into natural logarithmic form; $\gamma_{\mathrm{t}}$ is time varying attributes of country and $\alpha_{\mathrm{i}}$ stands for time invariant unobserved country heterogeneity. In a panel data setting, pooled OLS produced bias estimates when the unobserved country specific $\alpha_{i}$ is correlated with the error term. Therefore, in order to produce efficient and unbiased estimates fixed effect and random effect model is estimated, then a valid model is chosen by Hausman test (Hausman, 1978). Under the null hypothesis that independent variables are uncorrected with error terms, random effect model is appropriate. On the contrary, fixed effect model is chosen if the null hypothesis is rejected. Some previous studies pointed out the endogeneity of FDI (Bao, Chen, \& Song, 2011; Liang, 2008; Wang \& Chen, 2014): FDI may affect pollution but pollution is also likely to affect FDI. FDI companies may find polluted regions less attractive so invest less in these regions. In this case, instrumental variables are used as a proxy for the endogenous variable FDI. Following literature, FDI one lag period is chosen as the instrumental variable for FDI. 


\section{Results and Discussion}

From the Hausman test, the $\mathrm{P}$ value $=0.00<0.05$ so the null hypothesis is rejected, fixed effect model is chosen. However, given the endogeneity of FDI, fixed effect model with instrumental variable - one lag period of FDI is the appropriate model. In the fixed effect -IV model, FDI has a significantly positive effect on $\mathrm{CO} 2$ emission in the five ASEAN countries. A one percent increase in FDI is associated with $0,19 \%$ increase in pollution. In all three-equation models, energy consumption significantly leads to $\mathrm{CO} 2$ emission. The magnitude of pollution associated with energy consumption is relatively high

Table 4.1: Empirical results of foreign direct investment on $\mathrm{CO} 2$ emission

\begin{tabular}{|l|l|l|l|}
\hline \multicolumn{3}{|l|}{ Dependent variable: lnCo2 } & Fixed effect -IV \\
\hline Infdi & Fixed effect & Random effect & $0.1990858^{*}$ \\
\hline Intrade & 0.371086 & 0.0544584 & 0.0399807 \\
\hline lnurban & $0.187382^{*}$ & -0.0751434 & 0.7829563 \\
\hline lnenergy & 0.0683066 & $0.6610371^{*}$ & $0.7662949^{*}$ \\
\hline Instrumental variable: FDI one lag period & $1.107509^{*}$ & $1.178216^{*}$ & \\
\hline
\end{tabular}

Note: * indicates significant at 5\% level

\section{Conclusions}

This article aims to examine the effect of $\mathrm{CO} 2$ emission in five ASEAN countries, namely Cambodia, Thailand, Vietnam, the Philippines, and Malaysia using data from World Development Indicator in 1996-2013 period. Trade and urbanization do not cause the increase in $\mathrm{CO} 2$ emission. However, the pollution haven hypothesis is confirmed in these countries. The result for ASEAN countries is similar to Baek (2016), Guzel and Okumus (2020), Merican et al. (2007), Zhu et al. (2016). Although FDI is considered to be the engine of growth in this dynamic economic zone, it is important for these countries to be careful in attracting FDI. Host countries should assess environmental impacts of FDI projects before implementing. In addition, as energy consumption is proved to worsen environment, ASEAN countries should use energy effectively and have programs to develop clean renewable energy sources instead of using fossil fuels.

\section{Reference}

[1] Ansari, M. A., Khan, N. A., \& Ganaie, A. A. (2019). Does foreign direct investment impede environmental quality in Asian countries? A panel data analysis. OPEC Energy Review, 43(2), 109-135. doi:10.1111/opec. 12144

[2] Atici, C. (2012). Carbon emissions, trade liberalization, and the Japan-ASEAN interaction: A group-wise examination. Journal of the Japanese and international economies, 26(1), 167-178. doi:10.1016/j.jjie.2011.07.006

[3] Azam, M., Khan, A. Q., Zaman, K., \& Ahmad, M. (2015). Factors determining energy consumption: Evidence from
Indonesia, Malaysia and Thailand. Renewable and Sustainable Energy Reviews, 42, 1123-1131. doi:https://doi.org/10.1016/j.rser.2014.10.06 $\underline{1}$

[4] Baek, J. (2016). A new look at the FDIincome-energy-environment nexus: Dynamic panel data analysis of ASEAN. Energy Policy, 91, 22-27. doi:10.1016/j.enpol.2015.12.045

[5] Bakirtas, I., \& Cetin, M. A. (2017). Revisiting the environmental Kuznets curve and pollution haven hypotheses: MIKTA sample. Environ Sci Pollut Res Int, 24(22), 18273-18283. doi:10.1007/s11356-0179462-y

[6] Bao, Q. U. N., Chen, Y., \& Song, L. (2011). Foreign direct investment and environmental pollution in China: a simultaneous equations estimation. Environment and development economics, 16(1), 71-92. doi:10.1017/S1355770X10000380

[7] Cai, X., Lu, Y., Wu, M., \& Yu, L. (2016). Does environmental regulation drive away inbound foreign direct investment? Evidence from a quasi-natural experiment in China. Journal of Development Economics, $\quad$ 123, 73-85. doi:10.1016/j.jdeveco.2016.08.003

[8] Chandran, V. G. R., \& Tang, C. F. (2013). The impacts of transport energy consumption, foreign direct investment and income on $\mathrm{CO} 2$ emissions in ASEAN-5 economies. Renewable \& sustainable 
energy reviews, $24, \quad 445-453$. doi:10.1016/j.rser.2013.03.054

[9] Chung, S. (2014). Environmental regulation and foreign direct investment: Evidence from South Korea. Journal of Development Economics, $\quad 108, \quad 222-236$. doi:10.1016/j.jdeveco.2014.01.003

[10] Cole, M., Elliott, R., \& Zhang, L. (2017). Foreign Direct Investment and the Environment. Annual Review of Environment and Resources, 42, 465-487. doi:10.1146/annurev-environ-102016060916

[11] Cole, M. A. (2004). Trade, the pollution haven hypothesis and the environmental Kuznets curve: examining the linkages. Ecological Economics, 48(1), 71-81. doi:10.1016/j.ecolecon.2003.09.007

[12] Cole, M. A., \& Elliott, R. J. R. (2005). FDI and the Capital Intensity of "Dirty" Sectors: A Missing Piece of the Pollution Haven Puzzle. Review of Development Economics, 9(4), 530-548. doi:10.1111/j.14679361.2005.00292.x

[13] Cole, M. A., \& Fredriksson, P. G. (2009). Institutionalized pollution havens. Ecological Economics, 68(4), 1239-1256. doi:https://doi.org/10.1016/j.ecolecon.2008. $\underline{08.011}$

[14] Copeland, B. R., \& Taylor, M. S. (2004). Trade, Growth, and the Environment. Journal of economic literature, 42(1), 7-71. doi: $10.1257 / 002205104773558047$

[15] Crenshaw, E. M., \& Jenkins, J. C. (1996). Social Structure and Global Climate Change: Sociological Propositions concerning the Greenhouse Effect. Sociological focus (Kent, Ohio), 29(4), 341358. doi:10.1080/00380237.1996.10570650

[16] Dean, J. M., Lovely, M. E., \& Wang, H. (2009). Are foreign investors attracted to weak environmental regulations? Evaluating the evidence from China. Journal of Development Economics, 90(1), 1-13. doi:10.1016/j.jdeveco.2008.11.007

[17] Demena, B. A., \& Afesorgbor, S. K. (2020). The effect of FDI on environmental emissions: Evidence from a meta-analysis. Energy Policy, 138, 111192. doi:10.1016/j.enpol.2019.111192

[18] Destek, M. A., \& Okumus, I. (2019). Does pollution haven hypothesis hold in newly industrialized countries? Evidence from ecological footprint. Environ Sci Pollut Res Int, 26(23), 23689-23695. doi:10.1007/s11356-019-05614-z

[19] Fredriksson, P. G., List, J. A., \& Millimet, D. L. (2003). Bureaucratic corruption, environmental policy and inbound US FDI:

\section{ISSN 2455-6378}

theory and evidence. Journal of Public Economics, $\quad$ 87(7), 1407-1430. doi:10.1016/S0047-2727(02)00016-6

[20] Grossman, G., \& Krueger, A. (1991). Environmental Impacts of a North American Free Trade Agreement. NBER Working Paper Series, 3914. doi:10.3386/w3914

[21] Grossman, G. M., \& Krueger, A. B. (1992). Environmental Impacts of a North American Free Trade Agreement. Discussion paper series - Centre for Economic Policy Research(644).

[22] Guzel, A. E., \& Okumus, İ. (2020). Revisiting the pollution haven hypothesis in ASEAN-5 countries: new insights from panel data analysis. Environ Sci Pollut Res Int, 27(15), 18157-18167. doi:10.1007/s11356-020-08317-y

[23] Hanif, I., Faraz Raza, S. M., Gago-deSantos, P., \& Abbas, Q. (2019). Fossil fuels, foreign direct investment, and economic growth have triggered $\mathrm{CO} 2$ emissions in emerging Asian economies: Some empirical evidence. Energy (Oxford), 171, 493-501. doi:10.1016/j.energy.2019.01.011

[24]Hanna, R. (2010). US Environmental Regulation and FDI: Evidence from a Panel of US-Based Multinational Firms. American Economic Journal: Applied Economics, 2, 158-189. doi:10.1257/app.2.3.158

[25] Hausman, J. A. (1978). Specification Tests in Econometrics. Econometrica, 46(6), 1251-1271. doi:10.2307/1913827

[26] Hoffmann, R., Lee, C. G., Ramasamy, B., \& Yeung, M. (2005). FDI and pollution: a granger causality test using panel data. Journal of International Development, 17(3), 311-317. doi:10.1002/jid.1196

[27] Javorcik, B. S., \& Wei, S.-J. (2003). Pollution Havens and Foreign Direct Investment: Dirty Secret or Popular Myth? Contributions to economic analysis \& policy, 3(2). doi:10.2202/1538-0645.1244

[28] Kahia, M., Ben Jebli, M., \& Belloumi, M. (2019). Analysis of the impact of renewable energy consumption and economic growth on carbon dioxide emissions in 12 MENA countries. Clean technologies and environmental policy, 21(4), 871-885. doi:10.1007/s10098-019-01676-2

[29] Kahouli, B., \& Omri, A. (2017). Foreign direct investment, foreign trade and environment: New evidence from simultaneous-equation system of gravity models. Research in international business and finance, 42, 353-364. doi:10.1016/j.ribaf.2017.07.161 
[30] Kearsley, A., \& Riddel, M. (2010). A further inquiry into the Pollution Haven Hypothesis and the Environmental Kuznets Curve. Ecological Economics, 69(4), 905919. doi:10.1016/j.ecolecon.2009.11.014

[31] Khan, M. (2018). FDI Inflows and Environment in India. Academic Journal of Economic Studies, 4(3), 138.

[32]Khan, M. A., \& Ozturk, I. (2020). Examining foreign direct investment and environmental pollution linkage in Asia. Environ Sci Pollut Res Int, 27(7), 72447255. doi:10.1007/s11356-019-07387-x

[33] Koçak, E., \& Şarkgüneşi, A. (2018). The impact of foreign direct investment on $\mathrm{CO} 2$ emissions in Turkey: new evidence from cointegration and bootstrap causality analysis. Environmental science and pollution research international, 25(1), 790-804. doi:10.1007/s11356-017-0468-2

[34]Liang, F. (2008). Does Foreign Direct Investment Harm the Host Country's Environment? Evidence from China. SSRN Electronic Journal. doi: $10.2139 /$ ssrn. 1479864

[35] List, J. A., \& Co, C. Y. (2000). The Effects of Environmental Regulations on Foreign Direct Investment. Journal of Environmental Economics and Management, $\quad 40(1), \quad 1-20$. doi:10.1006/jeem.1999.1095

[36] List, J. A., McHone, W. W., \& Millimet, D. L. (2004). Effects of environmental regulation on foreign and domestic plant births: is there a home field advantage? Journal of urban economics, 56(2), 303326. doi:10.1016/j.jue.2004.03.007

[37] Liu, J., Qu, J., \& Zhao, K. (2019). Is China's development conforms to the Environmental Kuznets Curve hypothesis and the pollution haven hypothesis? Journal of Cleaner Production, 234, 787-796. doi:10.1016/j.jclepro.2019.06.234

[38] Matthew, A. C., Robert, J. R. E., \& Per, G. F. (2006). Endogenous Pollution Havens: Does FDI Influence Environmental Regulations? The Scandinavian journal of economics, 108(1), 157-178. doi:10.1111/j.1467-9442.2006.00439.x

[39] McGranahan, G. (2001). The citizens at risk : from urban sanitation to sustainable cities. London: Earthscan.

[40] McGuire, M. C. (1982). Regulation, factor rewards, and international trade. Journal of Public Economics, 17(3), 335-354. doi:10.1016/0047-2727(82)90069-X

[41] Merican, Y., Yusop, Z., Noor, Z., \& Law, S. (2007). Foreign Direct Investment and the Pollution in Five ASEAN Nations.
ISSN 2455-6378

International Journal of Economics and Management, 1.

[42] Millimet, D. L., \& Roy, J. (2016). Empirical Tests of the Pollution Haven Hypothesis When Environmental Regulation is Endogenous: EMPIRICAL TESTS OF THE POLLUTION HAVEN HYPOTHESIS. Journal of applied econometrics (Chichester, England), 31(4), 652-677. doi:10.1002/jae.2451

[43] Mol, A. P. J., \& Spaargaren, G. (2000). Ecological modernisation theory in debate: A review. Environmental politics, 9(1), 1749. doi:10.1080/09644010008414511

[44] Naughton, H. T. (2014). To shut down or to shift: Multinationals and environmental regulation. Ecological Economics, 102, 113-117. doi:10.1016/j.ecolecon.2014.03.013

[45] Omri, A., Nguyen, D. K., \& Rault, C. (2014). Causal interactions between CO2 emissions, FDI, and economic growth: Evidence from dynamic simultaneousequation models. Economic modelling, 42, 382-389. doi:10.1016/j.econmod.2014.07.026

[46]Pao, H.-T., \& Tsai, C.-M. (2011). Multivariate Granger causality between $\mathrm{CO} 2$ emissions, energy consumption, FDI (foreign direct investment) and GDP (gross domestic product): Evidence from a panel of BRIC (Brazil, Russian Federation, India, and China) countries. Energy (Oxford), $36(1)$, 685-693. doi:10.1016/j.energy.2010.09.041

[47] Pethig, R. (1976). Pollution, welfare, and environmental policy in the theory of Comparative Advantage. Journal of Environmental Economics and Management, 2(3), 160-169. doi:10.1016/0095-0696(76)90031-0

[48]Ren, S., Yuan, B., Ma, X., \& Chen, X. (2014). International trade, FDI (foreign direct investment) and embodied $\mathrm{CO} 2$ emissions: A case study of Chinas industrial sectors. China Economic Review, 28, 123134.

doi:https://doi.org/10.1016/j.chieco.2014.01 .003

[49] Rezza, A. A. (2013). FDI and pollution havens: Evidence from the Norwegian manufacturing sector. Ecological Economics, $\quad 90, \quad 140-149$. doi:10.1016/j.ecolecon.2013.03.014

[50] Sabir, S., Qayyum, U., \& Majeed, M. (2020). FDI and environmental degradation: the role of political institutions in South Asian countries. Environmental Science and 
Pollution Research. doi:10.1007/s11356020-09464-y

[51] Sadorsky, P. (2014). The effect of urbanization on $\mathrm{CO} 2$ emissions in emerging economies. Energy Economics, 41, 147153. doi:10.1016/j.eneco.2013.11.007

[52] Salehnia, N., Karimi Alavijeh, N., \& Salehnia, N. (2020). Testing Porter and pollution haven hypothesis via economic variables and $\mathrm{CO} 2$ emissions: a crosscountry review with panel quantile regression method. Environmental science and pollution research international, 27(25), 31527-31542. doi:10.1007/s11356020-09302-1

[53] Sapkota, P., \& Bastola, U. (2017). Foreign direct investment, income, and environmental pollution in developing countries: Panel data analysis of Latin America. Energy Economics, 64, 206-212. doi:10.1016/j.eneco.2017.04.001

[54] Sarkodie, S. A., \& Strezov, V. (2019). Effect of foreign direct investments, economic development and energy consumption on greenhouse gas emissions in developing countries. Sci Total Environ, 646 , 862-871. doi:10.1016/j.scitotenv.2018.07.365

[55] Shao, Q., Wang, X., Zhou, Q., \& Balogh, L. (2019). Pollution haven hypothesis revisited: A comparison of the BRICS and MINT countries based on VECM approach. Journal of Cleaner Production, 227, 724738. doi:10.1016/j.jclepro.2019.04.206

[56] Shen, J., Wang, S., Liu, W., \& Chu, J. (2019). Does migration of pollutionintensive industries impact environmental efficiency? Evidence supporting "Pollution Haven Hypothesis". J Environ Manage, 242 , 142-152. doi:10.1016/j.jenvman.2019.04.072

[57] Solarin, S. A., Al-Mulali, U., Musah, I., \& Ozturk, I. (2017). Investigating the pollution haven hypothesis in Ghana: An empirical investigation. Energy (Oxford), 124, 706-719. doi:10.1016/j.energy.2017.02.089

\section{ISSN 2455-6378}

[58] Sun, C., Zhang, F., \& Xu, M. (2017). Investigation of pollution haven hypothesis for China: An ARDL approach with breakpoint unit root tests. Journal of Cleaner Production, 161, 153-164. doi:10.1016/j.jclepro.2017.05.119

[59] Tang, J. (2015). Testing the Pollution Haven Effect: Does the Type of FDI Matter? Environmental \& resource economics, 60(4), 549-578. doi:10.1007/s10640-014-9779-7

[60] UNCTAD. (2019). World Investment Report 2019. Retrieved from

[61] UNCTAD. (2020). World Investment Report 2020. Retrieved from

[62] Wang, D. T., \& Chen, W. Y. (2014). Foreign direct investment, institutional development, and environmental externalities: Evidence from China. Journal of Environmental Management, 135, 81-90. doi:10.1016/j.jenvman.2014.01.013

[63] Wolfgang, K., \& Arik, L. (2002). Pollution Abatement Costs and Foreign Direct Investment Inflows to U.S. States. The review of economics and statistics, 84(4), 691-703. doi:10.1162/003465302760556503

[64] Xing, Y., \& Kolstad, C. D. (2002). Do Lax Environmental Regulations Attract Foreign Investment? Environmental \& resource economics, $21(1), \quad 1-22$. doi:10.1023/A:1014537013353

[65]Zeng, K., \& Eastin, J. (2012). Do Developing Countries Invest Up? The Environmental Effects of Foreign Direct Investment from Less-Developed Countries. World Development, 40(11), 2221-2233. doi:10.1016/j.worlddev.2012.03.008

[66]Zhu, H., Duan, L., Guo, Y., \& Yu, K. (2016). The effects of FDI, economic growth and energy consumption on carbon emissions in ASEAN-5: Evidence from panel quantile regression. Economic modelling, $\quad 58, \quad 237-248$. doi:10.1016/j.econmod.2016.05.003 